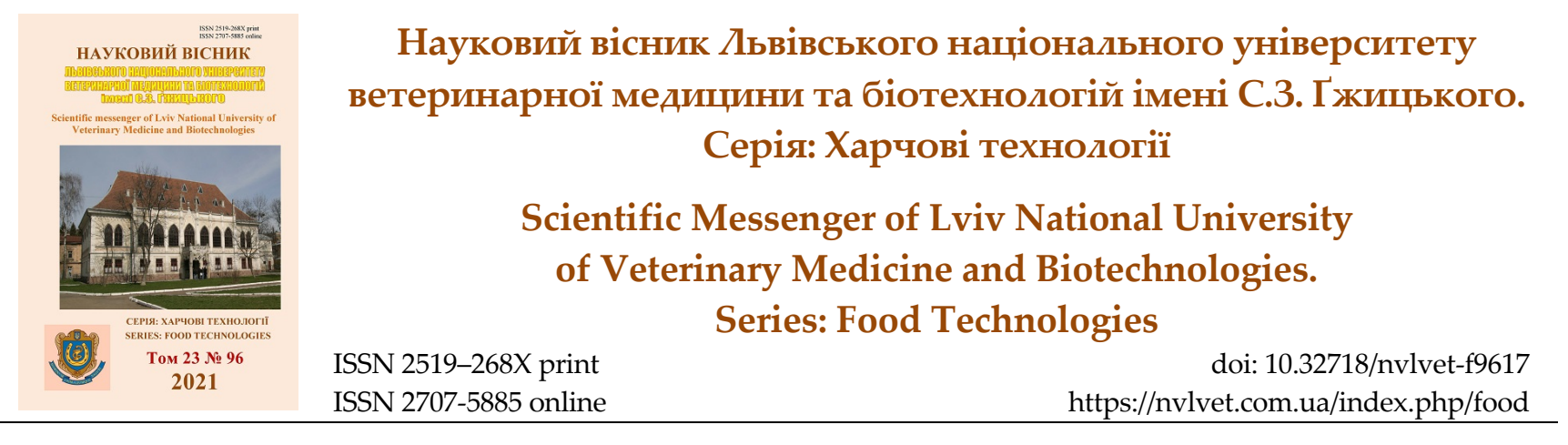

UDC 638.16:664.3

\title{
Evaluation of honey as a dessert in hotel and restaurant complexes
}

\author{
S. Merzlov, Yu. Shurchkova, V. Nedashkivskyi, G. Merzlova, N. Nedashkivska \\ Bila Tserkva National Agrarian University, Bila Tserkva, Ukraine
}

Article info

Received 17.06.2021

Received in revised form 19.07.2021

Accepted 20.07.2021

Bila Tserkva National Agrarian University, Pl. Soborna 8/1, Bila Tserkva, 09117, Ukraine. Tel. : +38-098-783-72-15 E-mail: NNV2020@ukr.net
Merzlov, S., Shurchkova, Yu., Nedashkivskyi, V., Merzlova, G., \& Nedashkivska, N. (2021). Evaluation of honey as a dessert in hotel and restaurant complexes. Scientific Messenger of Lviv National University of Veterinary Medicine and Biotechnologies. Series: Food Technologies, 23(96), 102-105. doi: 10.32718/nvlvet-f9617

The article presents the results of research of honey as a dessert in hotel and restaurant complexes of Bila Tserkva region. The analysis of researched samples of honey with the use of laboratory researches which were carried out in the conditions of scientific laboratory of chair of safety and quality of foodstuff, raw materials and technological processes of Bila Tserkva national agrarian university is carried out. The research was conducted in accordance with the national standard of Ukraine DSTU 4497. according to generally accepted methods. Color, taste, aroma, consistency, crystallization, signs of fermentation were determined organoleptically using the sensory method of analysis of honey. It was found that in all samples the color of honey was from light yellow to yellow, with a pleasant taste and aroma, without signs of fermentation and the content of mechanical and other impurities. The diastasis number of honey samples used by hotel and restaurant complexes is 14, 10 and 8 units, respectively. Goethe, which indicates the heating of part of the honey. Thus, the results of research have shown that honey, which is used in hotel and restaurant complexes of Bila Tserkva region as a dessert in terms of organoleptic indicators, meets the requirements of the national state standard.

Key words: sugar mixture, fructose, glucose, national standard.

\section{Оцінка меду як десерту в готельно-ресторанних комплексах}

\author{
С. В. Мерзлов, Ю. О. Шурчкова, В. М. Недашківський, Г. В. Мерзлова, Н. В. Недашківська
}

Білоиерківський національний аграрний університет, м. Біла Церква, Украӥна

\footnotetext{
У статті викладені результати досліджень меду як десерту в готельно-ресторанних комплексах Білочерківщини. Проведено аналіз досліджуваних зразків меду з використанням лабораторних досліджень, які проводились в умовах наукової лабораторії кафедри безпечності та якості харчових продуктів, сировини та технологічних процесів Білоцерківського національного аграрного університету. Дослідження проводили згідно національного стандарту України ДСТУ 4497. за загальноприйнятими методиками. Колір, смак, аромат, консистенцію, кристалізацію, ознаки бродіння визначали органолептично, використовуючи сенсорний метод аналізу меду. Встановлено, що у всіх зразках мед за кольором був від світложовтого до жовтого кольору, із приємним смаком та ароматом, без ознак процесу бродіння та вмісту механічних та інших домішок. Діастазне число досліджуваних зразків меду, які використовую готельно-ресторанні комплекси становить відповідно 14, 10 та 8 од. Готе, що свідчить про нагрівання частини меду. Отже, результати досліджень показали, щьо мед, який використовується у готельно-ресторанних комплексах Білоцерківщини як десерт за органолептичними показниками відповідає вимогам національного державного стандарту.
}

Ключові слова: суміш иукрі, фруктоза, глюкоза, начіональний стандарт. 


\section{Вступ}

В даний час світові тенденції культури харчування змінюються i більшість людей відмовляються від цукру на користь меду. Зокрема, останніми роками зафіксовано, що у багатьох країнах мед $є$ головним інгредієнтом для приготування десертів і солодощів (Tsisaryk et al., 2016; Bal-Prylypko et al., 2018).

На сьогоднішній день мед набуває все більш широку популярність не тільки як продут високих харчових і дієтичних достоїнств, але і як лікарський засіб у профілактиці та лікуванні ряду захворювань (Taranov, 2005; Kovalchuk et al., 2019; Piven et al., 2020; Khamid \& Danchuk, 2021).

До складу меду входять речовини 3 лікувальнопрофілактичними властивостями, які роблять даний продукт затребуваним. Його властивості унікальні адже він $є$ природним енергетиком, імуностимулюючим засобом, антисептиком, позитивно впливає на внутрішні органи людини і з давніх давен використовується для профілактики простудних захворювань.

Слід зазначити, що мед особливо для любителів поїсти не тільки не дає поправитися, а навпаки - сприяє схудненню і оздоровленню тіла. Оскільки, мед є натуральною сумішшю цукрів, його можна використовувати для екстреного насичення організму і отримання швидкого заряду бадьорості. Необхідно зазначити, що мед майже на третину складається з глюкози - найбільш доступного і універсального джерела енергії для всіх живих істот, включаючи людину. Ще на третину він складається 3 фруктози, визнаної щодо “безпечності” аналогом звичайного цукру. Фруктоза здатна засвоюватися організмом практично без участі інсуліну, що робить їі більш корисною для людей із порушеним вуглеводневим обміном (Burmistrova et al., 2010; Meo et al., 2017).

Експериментально доведено, що мед майже цілком складається з вуглеводів: 38 \% - фруктози, $31 \%$ глюкози, $1 \%$ - сахарози та 9 \% інших органічних цукрів (мальтози та ін.). До того як люди навчилися виробляти цукор з буряка і цукрової тростини, мед був чи не єдиним натуральним підсолоджувачем. Однак, крім цукрів, у меді містяться й інші речовини: фолієва кислота (вітамін В9), каротин (провітамін вітаміну А), вітаміни $\mathrm{B}_{1}, \mathrm{~B}_{2}, \mathrm{~B}_{6}, \mathrm{E}, \mathrm{K}$, аскорбінова кислота, амінокислоти (аланін, аргінін, аспарагінова i глутамінова кислоти, лейцин, лізин, фенілаланін, тирозин, треонін, в деяких сортах також метіонін, триптофан і пролін) і ензими каталаза, амілаза, діастаза, фосфатаза.

Зокрема, у невеликій кількості в усіх видах меду зустрічаються органічні і неорганічні кислоти такі як яблучна, лимонна, молочна, щавлева, винна, лінолева.

Мінеральні речовини в меді становлять в середньому 0,27 \% і представлені 37 хімічними елементами, які регулюють обмін речовин в організмі. Найбільшу кількість 3 них займають - Калій, Натрій, Магній, Ферум, Манган, Кобальт. Проте, мед різного ботанічного походження може відрізнятися за цим показником (Vakulenko, 2008; Koval's'kyy \& Kyryliv, 2011).
Дослідженнями встановлено, що мед може не псуватися роками, а іноді й десятиліттями, вчені пояснюють дану особливість двома факторами. По-перше, що для свіжого меду характерна рідка форма, тому в медові дуже мало вологи і бактерії не можуть в ньому розмножуватися. По-друге, його водневий показник (pH) коливається від 3 до 4,5, тобто в медові - кисле середовище, що вбиває хвороботворні мікроорганізми. Однак, є виняток, наближений до нейтрального $\mathrm{pH}$ має тільки липовий мед (4,5-7).

Одними з основних чинників зростання попиту на мед в харчовій індустрії $є$ популяризація здорового способу життя та зростаючі вимоги споживачів до складу і якості їжі, що споживається.

Крім цього переліку, сам по собі, натуральний мед $\epsilon$ смачним десертом. Також мед добре використовувати як добавки в різні кулінарні страви, наприклад, як корисний підсолоджувач. Оскільки, мед є натуральною альтернативою цукру і штучних підсолоджувачів. Зростає популярність меду зі знаком “есо", а також продуктів на основі меду (медові суфле, мед 3 додаванням фруктів і ягід, медові сорбети і щербети) (Chepurnoy, 2002; Namias, 2003; Honnje \& Vash, 2012).

На даний час в доступній літературі мало зустрічається інформації щодо якості меду, що використовується в готелях та ресторанах центральної України.

Метою досліджень була перевірка основних показників якості меду в готельно-ресторанних комплексах Білоцерківщини та їх відповідність до вимог національних стандартів.

\section{Матеріал і методи досліджень}

Лабораторні дослідження зразків меду проводили в умовах наукової лабораторії кафедри безпечності та якості харчових продуктів, сировини та технологічних процесів Білоцерківського національного аграрного університету.

Матеріалом для досліджень слугував квітковий мед різних виробників, який використовують як десерт готельно-ресторанні комплекси Білоцерківщини. Для дослідження були відібрані зразки № 1, 2 та 3. Перші зразки- квітковий мед, який використовують готельно-ресторанні комплекси розміщений в центрі міста Білої Церкви, 2-гі зразки - мед квітковий, який подають в готельно-ресторанних комплексах розміщених на околиці міста, треті зразки - мед квітковий, що застосовують у готельно-ресторанних комплексах Білоцерківського району. Досліджували зразки меду фасованого по 50 г.

Дослідження проводили згідно національного стандарту України ДСТУ 4497:2005 “Мед натуральний. Технічні умови” (DSTU 4497:2005) за загальноприйнятими методиками. Колір, смак, аромат, консистенцію, кристалізацію, ознаки бродіння визначали органолептично, використовуючи сенсорний метод аналізу меду; механічні домішки - методом повного розчинення меду в воді; наявність паді - якісною (спиртовою) реакцією; натуральність меду - визначенням діастазного числа.

Одержані експериментальні результати порівнювали з вимогами ДСТУ 4497:2005 (DSTU 4497:2005). 


\section{Результати та їх обговорення}

Аналізуючи показники наведені в таблиці 1 , слід зазначити, що квітковий мед, в дослідних зразках за кольором змінюється від світло-жовтого до жовтого.

За смаком, даним зразкам меду притаманний приємно-солодкий смак однак мед, у 1 і 2 зразках має характерний легкий присмак гіркоти.

Встановлено, що аромат досліджуваних зразків меду змінюється від приємно ніжного, зразки №3 до сильного аромату зразки №1 та 2.
Консистенція у досліджуваних зразках була в основному щільна, зокрема, у другому та третьому зразках меду. Мед із перших зразків мав середню в'язкість.

За показником, як кристалізація у перших двох зразках меду виявили малі дрібні кристали, проте у третьому зразку встановлено великі кристали.

Для всіх зразків досліджуваного меду, відсутні ознаки бродіння та невиявлено механічних домішок.

\section{Таблиця 1}

Органолептичні показники меду

\begin{tabular}{|c|c|c|c|c|}
\hline Показник & За ДСТУ 4497:2005 & Зразки №1 & Зразки №2 & Зразки №3 \\
\hline Колір & $\begin{array}{l}\text { Безбарвний, білий, світложо- } \\
\text { втий, жовтий, темножовтий, } \\
\text { темний з різними відтінками }\end{array}$ & Жовтий & Жовтий & Світло-жовтий \\
\hline Смак & $\begin{array}{c}\text { Солодкий, ніжний, приємний, } \\
\text { терпкий, подразнює слизову } \\
\text { оболонку ротової порожнини, } \\
\text { без сторонніх присмаків }\end{array}$ & $\begin{array}{c}\text { Солодкий, приєм- } \\
\text { ний, терпкий, } 3 \\
\text { легким присмаком } \\
\text { гіркоти } \\
\end{array}$ & $\begin{array}{c}\text { Приємний, } \\
\text { солодкий, з легким } \\
\text { присмаком гіркоти }\end{array}$ & $\begin{array}{c}\text { Солодкий, приємний, } \\
\text { подразнює слизову оболо- } \\
\text { нку ротової порожнини, } \\
\text { без сторонніх присмаків }\end{array}$ \\
\hline Аромат & $\begin{array}{c}\text { Специфічний, приємний, } \\
\text { слабкий, сильний, ніжний, без } \\
\text { сторонніх запахів }\end{array}$ & $\begin{array}{c}\text { Специфічний, при- } \\
\text { ємний, сильний, без } \\
\text { сторонніх запахів } \\
\end{array}$ & $\begin{array}{c}\text { Яскраво } \\
\text { виражений, сильно } \\
\text { солодкий } \\
\end{array}$ & $\begin{array}{c}\text { Специфічний, приємний, } \\
\text { ніжний, без сторонніх } \\
\text { запахів } \\
\end{array}$ \\
\hline Консистенція & $\begin{array}{c}\text { Рідка, в'язка, дуже в'язка, } \\
\text { щільна }\end{array}$ & Середньої в'язкості & Щільна & Щільна \\
\hline Кристалізація & $\begin{array}{l}\text { Від дрібнозернистої до } \\
\text { крупнозернистої }\end{array}$ & Дрібнозерниста & Дрібнозерниста & Крупнозерниста \\
\hline $\begin{array}{l}\text { Ознаки } \\
\text { бродіння }\end{array}$ & Не допускається & Відсутні & Відсутні & Відсутні \\
\hline $\begin{array}{l}\text { Механічні } \\
\text { домішки }\end{array}$ & Не допускається & Не виявлено & Не виявлено & Не виявлено \\
\hline
\end{tabular}

Дослідження зразків меду за фізико-хімічними показниками наведено в таблиці 2.

Встановлено, що діастазне число досліджуваних зразків меду №1, 2, 3, які використовують готельноресторанні комплекси становить, відповідно, 14, 10 та 8 од. Готе. Даний показник показує рівень нагрівання і тривалість зберігання меду. Із даних випливає, що мед у пробах 2 та 3 піддався нагріванню.

Провівши якісну реакцію на наявність паді виявили відсутність падевого медозбору в усіх трьох досліджуваних зразках меду.

\section{Таблиця 2}

Фізико-хімічні показники меду квіткового різних виробників, $(\mathrm{n}=3)$

\begin{tabular}{lcccc}
\hline \multicolumn{1}{c}{ Показник } & За ДСТУ 4497:2005 & Зразки №1 & 3разки №2 & 3разки №3 \\
\hline $\begin{array}{l}\text { Діастазне число (до Безводної } \\
\text { речовини), од. Готе, не менше }\end{array}$ & Не менше 15,0 & 14 & 10 & 8 \\
$\begin{array}{l}\text { Якісна реакція на наявність } \\
\text { паді }\end{array}$ & $\begin{array}{c}\text { Негативна або молочно- } \\
\text { біла каламуть }\end{array}$ & Негативна & Негативна & Негативна \\
\hline
\end{tabular}

Важливим показником меду є якісна реакція на оксиметилфурфурол (табл. 3) Проведені дослідження дали змогу виявити, що у всі три зразки тривалий час зберігались, про що свідчить, позитивна реакція на оксиметилфурфурол та білий колір світіння зразків меду за люмінесцентного аналізу.

\section{Таблиця 3}

Визначення фальсифікації зразків меду

\begin{tabular}{|c|c|c|c|}
\hline Назва показника & Зразки №1 & Зразки №2 & Зразки №3 \\
\hline $\begin{array}{l}\text { Якісна реакція на оксиметилфурфурол (ОМФ) } \\
\text { Люмінесцентний аналіз }\end{array}$ & $\begin{array}{l}\text { позитивна } \\
\text { білий колір }\end{array}$ & $\begin{array}{l}\text { позитивна } \\
\text { білий колір }\end{array}$ & $\begin{array}{l}\text { позитивна } \\
\text { білий колір }\end{array}$ \\
\hline
\end{tabular}


Отже, дані дослідження комплексної оцінки меду показали, що за органолептичними показниками всі зразки меду, які використовують готельно-ресторанні комплекси м. Білої Церкви та району відповідають вимогам ДСТУ 4497.

\section{Висновки}

Мед, який використовується у готельноресторанних комплексах Білоцерківщини як десерт відповідає вимогам національного державного стандарту за органолептичними показниками. Готельноресторанні комплекси використовують мед після термічної обробки і тривалого терміну зберігання.

Перспективи подальших досліджень. Перспективним вбачається подальше проведення досліджень зразків меду різного ботанічного походження, які використовують готельно-ресторанні комплекси Білоцерківщини для порівняння із результатами зразків меду з інших регіонів України.

\section{References}

Bal-Prylypko, L., Lesnitska, O., \& Paska, M. (2018). Justification of the norms for the maximum permissible content of harmful substances in honey. Scientific Messenger of LNU of Veterinary Medicine and Biotechnologies. Series: Food Technologies, 20(85), 162-165. doi: 10.15421/nvlvet8529.

Burmistrova, L. A., Rusakova, T. M., \& Repnikova, T. M. (2010). Produkty pchelovodstva. Issledovanie mineral'nogo sostava. Sbornik nauchnyh rabot. Novoe v nauke i praktike pchelovodstva (k 80-letiju HNUNII pchelovodstva Ros sel'khoz akademii). Rybnoe: NIIP, 188-192 (in Russian).

Chepurnoy, Y. P. (2002). Ekspertyza kachestva meda. Pchelovodstvo, 1, 48-50 (in Russian).

Chuhunova, O. V., \& Zavorokhyna, N. V. (2010). Ispol'zovanye metodov dehustatsyonnoho analiza pri modelyrovanyy retseptur pyshchevykh produktov s 137 zadannymy potrebytel'skymy svoystvamy: monohrafiya; M-vo obrazovanyya y nauky RF, Ural. hos. эkon. un-t. Ekaterynburh : Izd-vo Ural. hos. ekon. un (in Russian).

Honnje, M., \& Vash, H. (2012). Degustacija meda. Sensornyj analiz. UNAFAPIMONDIA. Parizh, Buharest (in Russian).

Khamid, K., \& Danchuk, O. (2021). Evaluation of quality indicators of honey ofdifferent origin. Agrarian bulletin of the black sea littoral. Scientific journal, 98, 111114.
Kovalchuk, I., Dvylyuk, I., Lecyk, Y., Dvylyuk, I., \& Gutyj, B. (2019). Physiological relationship between content of certain microelements in the tissues of different anatomic sections of the organism of honey bees exposed to citrates of argentum and cuprum. Regulatory Mechanisms in Biosystems, 10(2), 177181. doi: 10.15421/021926.

Koval's'kyy, Yu. V., \& Kyryliv, Ya. I. (2011). Deyaki aspekty yakosti medu. Zbirnyk naukovykh prats' Vinnyts'koho natsional'noho ahrarnoho universytetu. Bezpeka produktiv kharchuvannya ta tekhnolohiya pererobky, 11(51), 157-160 (in Ukrainian).

Med natural'nyy. Tekhnichni vymohy: DSTU 4497:2005. [Chynnyy vid 2007-01-01]. K.: Derzhspozhyvstandart Ukrayiny, 2007. (Natsional'nyy standart Ukrayiny) (in Ukrainian).

Meo, S. A., Al-Asiri, S. A., \& Mahesar, A. L. (2017). Role of honey in modern medicine. Saudi journal of biological sciences, 24(5), 975-978. doi: 10.1016/j.sjbs.2016.12.010.

Namias, N. (2003). Evidence for the Antimicrobial Properties of Honey. Medscape, 15, 143-146

Piven, O. T., Khimych, M. S., Salata, V. Z., Gutyj, B. V., Naidich, O. V., Skrypka, H. A., Koreneva, Z. B., Dvylyuk, I. V., Gorobey, O. M., \& Rud, V. O. (2020). Contamination of heavy metals and radionuclides in the honey with different production origin. Ukrainian Journal of Ecology, 10(2), 405-409. URL: https://www.ujecology.com/articles/contmination-ofheavy-metals-and-radionuclides-in-the-honey-withdifferent-production-origin.pdf.

Pryymak, H. M. (2010). Osoblyvosti rozrakhunku efektyvnosti vyrobnytstva produktsiyi bdzhil'nytstva. Pasika, 10, 20-22 (in Ukrainian).

Taranov, H. F. (2005). O mede, eho kachestve i khranenyy. Pchelovodstvo, 1, 46-47 (in Russian).

Tsisaryk, O. Y., Musiy, L. Y., \& Shereshkova, O. (2016). Resistance to oxidation butter with nut-honey filler. Scientific Messenger of LNU of Veterinary Medicine and Biotechnologies. Series: Food Technologies, 18(1), 148-154. URL: https://nvlvet.com.ua/index.php/food/ article/view/3236.

Vakulenko, L. L. (2008). Teoretychni osnovy analizu rynku medu natural'noho: Zb. nauk. Pr. Khersons'koho derzh. ahrar. Un-tu. Tavriys'kyy nauk. Visnyk. Kherson, 58, 231-237 (in Ukrainian).

Viuda-Martos, M., Ruiz-Navajas, Y., Fernandez-Lopez, J., Perez-Alvarez, J. A. (2008). Functional Properties of Honey, Propolis, and Royal Jelly. Journal of Food Science, 73(9), 117-124. doi: 10.1111/j.17503841.2008.00966.x. 